\title{
Morphological characteristics and proportion of leaf blade tissues of elephant grass clones under sheep grazing
}

\author{
Bruno Leal Viana( ${ }^{(1)}$, Alexandre Carneiro Leão de Mello(1), Adriana Guim( ${ }^{(1)}$, Mário de Andrade Lira(1), \\ José Carlos Batista Dubeux Júnior ${ }^{(1)}$, Mércia Virgínia Ferreira dos Santos ${ }^{(1)}$ and Márcio Vieira da Cunha ${ }^{(1)}$ \\ (1)Universidade Federal Rural de Pernambuco, Departamento de Zootecnia, Avenida Dom Manuel de Medeiros, s/no, Dois Irmãos, CEP \\ 52171-900 Recife, PE, Brazil. E-mail: brunoviana.ufrpe@yahoo.com.br, mello@dz.ufrpe.br, aguim@dz.ufrpe.br, mariolira@terra.com.br, \\ dubeux@dz.ufrpe.br, mercia@dz.ufrpe.br, marcio.cunha@ufrpe.br
}

\begin{abstract}
The objective of this work was to characterize morphologically elephant grass (Pennisetum purpureum) genotypes and to estimate their proportions of leaf blade tissues under grazing. Two tall varieties (Elephant B and IRI-381) and three short ones (Mott, Taiwan A-146 2.37, and Taiwan A-146 2.114) were evaluated under intermittent sheep grazing as to the following morphological characteristics: plant height, internode length, and leaf blade/culm ratio. Moreover, the proportions of the following leaf blade tissues were estimated: sclerenchyma, adaxial and abaxial epidermis, bulliform cells, vascular bundles, phloem, vascular sheath, xylem, and mesophyll. The short varieties were $28.6 \%$ shorter than the tall ones and showed higher leaf blade/culm ratio; Mott and Taiwan A-146 2.114 had the shortest internodes of 3.9 and $4.7 \mathrm{~cm}$, respectively, over ten grazing cycles. The clones differed regarding their proportions of leaf blade tissues, except for abaxial epidermis, phloem, and xylem. The differences in morphological characteristics indicate that the short clones Mott and Taiwan A-146 2.114 are better adapted to sheep grazing, and, therefore, may be recommended for the improvement of pastures.
\end{abstract}

Index terms: Pennisetum purpureum, dwarf elephant grass, pasture management, plant anatomy, small ruminants.

\section{Características morfológicas e proporção de tecidos da lâmina foliar em clones de capim-elefante sob pastejo de ovelhas}

\begin{abstract}
Resumo-O objetivo deste trabalho foi caracterizar morfologicamente genótipos de capim-elefante (Pennisetum purpureum) e estimar as proporções de tecido de suas lâminas foliares, sob pastejo. Duas variedades altas (Elefante B e IRI-381) e três baixas (Mott, Taiwan A-146 2.37 e Taiwan A-146 2.114) foram avaliadas sob pastejo intermitente de ovelhas quanto às seguintes variáveis morfológicas: altura de planta, comprimento de entrenós e razão entre lâminas foliares e colmos. Além disso, foram estimadas as proporções dos seguintes tecidos da lâmina foliar: esclerênquima, epidermes adaxial e abaxial, células buliformes, feixes vasculares, floema, bainha vascular, xilema e mesófilo. As variedades baixas foram $28,6 \%$ menores do que as altas e apresentaram maiores razões entre lâminas foliares e colmos; Mott e Taiwan A-146 2.114 tiveram os menores entrenós de 3,9 e 4,7 cm, respectivamente, ao longo de dez ciclos de pastejo. Os clones diferiram quanto às proporções de tecidos da sua lâmina foliar, exceto para epiderme abaxial, floema e xilema. As diferenças nas características morfológicas indicam que os clones baixos Mott e Taiwan A-146 2.114 são melhores adaptados ao pastejo por ovelhas e, portanto, podem ser recomendados para o melhoramento de pastagens.
\end{abstract}

Termos para indexação: Pennisetum purpureum, capim-elefante anão, manejo de pastagens, anatomia de plantas, pequenos ruminantes.

\section{Introduction}

Elephant grass (Pennisetum purpureum Schumach.) has a high productive potential, which, combined with other favorable characteristics of this forage, such as quality, palatability, vigor, and persistence, has stimulated its breeding programs and cultivation. However, when used for pasture, the species may exhibit a limiting growth habit, with rapid elongation of internodes, which results in fast culm maturation (Veiga, 1994). This is problematic since shorter and tenderer plants, with a higher leaf blade/culm ratio, may be a more appropriate alternative for pastures, especially due to the greater ease of forage prehension by small ruminants. 
Short elephant grass clones have been shown to markedly differ morphologically and productively from tall ones (Silva et al., 1994; Almeida et al., 2000b), indicating that they may be an important alternative for animal production systems based on pastures. The increasing interest in the use of short clones in pasture systems is mainly attributed to their better prehension by animals and to the location of their apical meristems close to the ground, which reduces meristem decapitation and confers high persistence under grazing conditions (Resende et al., 2002; Silva et al., 2009; Viana et al., 2009; Araújo et al., 2011). However, there are few known reports on dwarf clones subjected to grazing by small ruminants (Viana et al., 2015).

The leaf blade/culm ratio is an important morphological trait for predicting forage nutritional value, as it indicates the proportion of stems present in the plant. Since the nutritional value of the stems is lower than that of the leaves, a higher proportion of leaf blades is desirable in pastures. This trait, therefore, is directly associated with forage quality and consumption, particularly for species with thicker culms, such as elephant grass.

According to Ferreira et al. (2007), due to their different digestibility potential, leaf blade tissues are closely related to animal digestibility and dry matter intake. Phloem, mesophyll, parenchymal sheath, parenchymal tissue, sclerenchyma, xylem, and epidermis present a decreasing potential of degradation. Paciullo et al. (2002) reported that some tissues can remain intact, even after 46 hours of ingestion, mainly the ones with a thick, lignified wall, such as the parenchymal sheath of bundles, sclerenchyma, xylem, and culm epidermis. However, some non-lignified tissues can also show low rates of ruminal digestion, depending on the time in which they are subjected to incubation.

Besides the use of chemical composition and digestibility to determine forage value, anatomical studies have become an auxiliary tool for selecting plants with greater qualitative potential. Knowledge of the anatomy of tropical forage grasses may aid in their better use as ruminant feed (Brito \& Deschamps et al., 2001). This way, a quantitative plant anatomy approach can represent a major contribution for forage quality studies, enabling relevant comparisons among species and even cultivars.
Furthermore, histological studies can improve the selection of forages, whose physical and chemical characteristics are directly impacted by leaf blade anatomical features (Lempp, 2007). Deschamps \& Brito (2001) used histological parameters to select shorter elephant grass cultivars with shorter and narrower leaf blades, as well as a better tissue arrangement and a lower degree of lignification, which could result in higher digestibility. This shows the relevance of the morphological characterization of elephant grass clones and of the acquisition of accurate information on their leaf blade tissue proportions under grazing by small ruminants.

The objective of this work was to characterize morphologically elephant grass genotypes and to estimate their proportions of leaf blade tissues under grazing.

\section{Materials and Methods}

The experiment was carried out at the experimental station of Instituto Agronômico de Pernambuco (IPA), in the municipality of Itambé, located at "Zona da Mata Seca", i.e., the dry forest region, of the state of Pernambuco, Brazil. The average annual temperature of the region, at $190-\mathrm{m}$ altitude, is $26^{\circ} \mathrm{C}$, whereas the historical average annual rainfall is $1,359 \mathrm{~mm}$ (Itep, 2012). The soil of the area is classified as an Argissolo Vermelho-Amarelo (Ultisol), with a sandy clay loam texture (Santos et al., 2006). The chemical analysis of the soil at the $0.00-0.20$-m layer showed the following results: $\mathrm{pH}\left(\mathrm{H}_{2} \mathrm{O}\right) 5.5,10.8 \mathrm{mg} \mathrm{dm}^{-3} \mathrm{P}$ (Mehlich-1), $0.22 \mathrm{cmol}_{\mathrm{c}} \mathrm{dm}^{-3} \mathrm{~K}^{+}, 0.4 \mathrm{cmol}_{\mathrm{c}} \mathrm{dm}^{-3} \mathrm{Al}^{3+}, 2.2 \mathrm{cmol}_{\mathrm{c}} \mathrm{dm}^{-3}$ $\mathrm{Ca}+\mathrm{Mg}$, cation exchange capacity of $5.3 \mathrm{cmol}_{\mathrm{c}} \mathrm{dm}^{-3}, 19$ $\mathrm{g} \mathrm{kg}^{-1}$ soil organic matter, and base saturation of $46 \%$.

Five elephant grass genotypes were evaluated: two tall ones, IRI-381 and Elephant B; and three short ones, Mott, Taiwan A-146 2.37, and Taiwan A-146 2.114 , in a randomized complete block design, with four replicates. The tall clones were recommended by Cunha et al. (2007) for intermittent grazing by cattle. Mott was selected in 1977 from a self-fertilized progeny of the cultivar Merkeron, in Georgia, USA, and introduced in Brazil in the beginning of the 1980s, where it has already been used in various pasture studies (Flores et al., 1993; Silva et al., 1994; Almeida et al., 2000a, 2000b; Viana et al., 2009). The Taiwan group is formed by short genotypes developed by the

Pesq. agropec. bras., Brasília, v.53, n.11, p.1268-1275, Nov. 2018 DOI: 10.1590/S0100-204X2018001100009 
breeding program of IPA/Universidade Federal de Pernambuco (Table 1).

The genotypes were planted on July 16, 2007, in grooves $1.0 \mathrm{~m}$ apart from each other, in $25-\mathrm{m}^{2}$ plots $(5 \times 5 \mathrm{~m})$, with $9 \mathrm{~m}^{2}(3 \times 3 \mathrm{~m})$ useful area. At the time of planting, the area was fertilized with $16 \mathrm{~kg} \mathrm{KCl}$ and $20 \mathrm{~kg}$ simple superphosphate $\left(18 \% \mathrm{P}_{2} \mathrm{O}_{5}\right)$ per plot, which corresponded to a dosage of 80 and $120 \mathrm{~K}_{2} \mathrm{O}$ and $\mathrm{P}_{2} \mathrm{O}_{5} \mathrm{~kg} \mathrm{ha}{ }^{1}$, respectively, distributed uniformly in the grooves. The elephant grass clones were managed using an intermittent stocking rate of 25 Santa Inês sheep, with mean initial live weight of $42 \mathrm{~kg}$, and the mob-grazing technique to obtain a mean residual height of $0.3 \mathrm{~m}$.

Morphological evaluations were performed between September 2008 and September 2010, totaling sixteen grazing cycles. Ten were short cycles with 32 days of rest each: first, second, fifth, sixth, seventh, eighth, ninth, tenth, fifteenth, and sixteenth cycles; and six were long cycles with 64 days of rest: third, fourth, eleventh, twelfth, thirteenth, and fourteenth cycles. The pastures were fertilized with $50 \mathrm{~kg} \mathrm{ha}^{-1} \mathrm{~N}$, using urea, after each cycle.

An accumulated rainfall of 2,261 $\mathrm{mm}$ was recorded throughout the experimental period, with $1,633.1 \mathrm{~mm}$ during the short cycles and $627.9 \mathrm{~mm}$ during the long ones (Figure 1).

The different rest periods were determined according to the mean height of the plants 32 days after resprouting: when the plants did not achieve the minimum height of $0.5 \mathrm{~m}$, the rest periods were increased to 64 days. Therefore, the criterion used for maintaining the animals in the pastures was the achievement or not of the desired mean residual height. In order to form more homogeneous plots, avoiding the variations due to the different cycle durations, only

Table 1. Group, size, and origin of the elephant grass (Pennisetum purpureum) genotypes evaluated.

\begin{tabular}{lccc}
\hline Genotype & Group & Size & Origin $^{(1)}$ \\
\hline Elephant B & Merker & Tall & CNPGL \\
IRI-381 & Napier & Tall & IPA/UFRPE \\
Mott & Merkeron & Dwarf & Georgia, USA \\
Taiwan A-146 2.114 & Napier & Dwarf & IPA/UFRPE \\
Taiwan A-146 2.37 & Napier & Dwarf & IPA/UFRPE \\
\hline
\end{tabular}

${ }^{(1)}$ CNPGL, Embrapa Gado de Leite; and IPA/UFRPE, Instituto Agronômico de Pernambuco/Universidade Federal Rural de Pernambuco. the morphological data from the ten short cycles were considered.

The morphological variables evaluated were plant height, internode length, and leaf blade/culm ratio. Prior to the entry of the animals (pre-grazing) in the pastures, the dry matter mass of green forage was estimated with the direct method, by cutting one clump of forage per plot - contained in a $0.5 \mathrm{~m}^{2}$ frame $(0.5 \times 1.0 \mathrm{~m})-, 5.0 \mathrm{~cm}$ above soil level. The frame was then placed in different positions inside the useful plot, in order to not repeat samplings in a same site. Four tillers were selected from each clone, and the leaf blade and culms plus sheaths were separated. Samples were pre-dried in a forced-air oven at $65^{\circ} \mathrm{C}$, for 72 hours. The dry matter mass of the green fraction of the leaf blades was divided by the dry matter mass of the culms plus sheaths to determine the leaf blade/culm ratio. The mean lengths of the first two internodes (from the base to the apex) of the same tillers used to obtain this ratio were measured using a caliper. The mean canopy height was estimated through five measurements per plot, considering the distance between the ground and the inflection of the highest leaf of the clump, using a measuring tape.

The material for the anatomical characterization of the tissues was collected in August, right before the beginning of the morphological evaluations at the eighth grazing cycle.

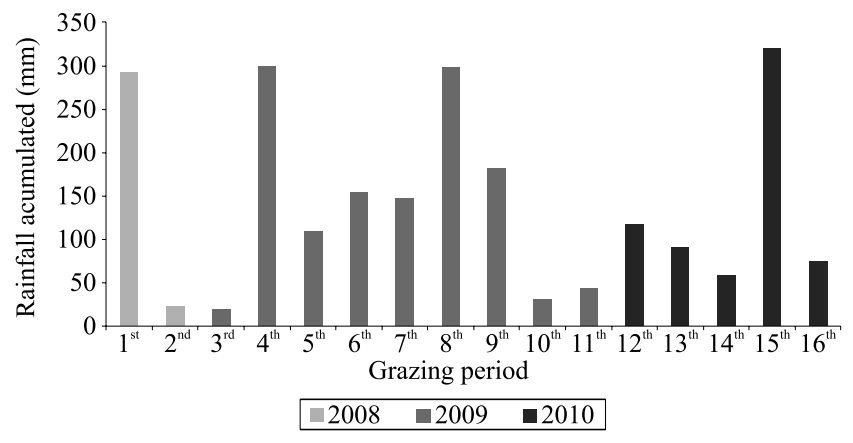

Figure 1. Accumulated rainfall at the experimental site after 16 grazing cycles, from September 2008 to September 2010. In 2008, during September and October; in 2009, January, March, April, May, June, August, September, October, and December; and in 2010, February, April, June, August, and September. Grazing cycles of 32 days: $1^{\text {st }}, 2^{\text {nd }}, 5^{\text {th }}, 6^{\text {th }}, 7^{\text {th }}, 8^{\text {th }}$, $9^{\text {th }}, 10^{\text {th }}, 15^{\text {th }}$, and $16^{\text {th }}$ cycles; and grazing cycles of 64 days: $3^{\text {rd }}, 4^{\text {th }}, 11^{\text {th }}, 12^{\text {th }}, 13^{\text {th }}$, and $14^{\text {th }}$ cycles. 
Using a $0.5-\mathrm{m}^{2}$ frame, three basal tillers were collected at ground level in the useful area of the plots. The middle portion of the leaf blade of the first completely expanded leaf from each tiller was sampled. Part of the material was fixed in 50\% formaldehyde:acetic acid:ethanol.

The data for the morphological variables were subjected to the analysis of variance, using the SAS software (SAS Institute Inc., Cary, NC, USA), considering a randomized block design, with measurements repeated in time, according to Vieira et al. (2007). Before this analysis, the sphericity test was performed to verify whether the covariance matrix satisfied the Huynh-Feldt condition. The multivariate analysis of repeated measurements in time was used when the sphericity test was significant at $1 \%$ probability. Means were compared by Tukey's test, at $5 \%$ probability. The estimated percentages of the leaf blade tissues were analyzed using the GLM procedure of SAS (SAS Institute Inc., Cary, NC, USA). Tukey's test, at $5 \%$ probability, was also used for comparison of means in this case.

\section{Results and Discussion}

The pre-grazing means for the leaf blade/culm ratio $(\mathrm{L} / \mathrm{C})$ varied from 0.33 for IRI-381, in the second cycle, to 1.97 for Taiwan A-146 2.114, in the ninth cycle (Table 2). Except in the eighth cycle, the L/C ratio differed among the five studied clones, with the short ones showing a larger proportion of leaf blades. Among the short clones, Mott $(\mathrm{L} / \mathrm{C}=1.47)$ and Taiwan A-146 $2.114(\mathrm{~L} / \mathrm{C}=1.37)$ had higher mean ratios along the ten cycles assessed. The tall clones showed the lowest L/C mean ratios -0.92 for IRI-381 and 0.91 for Elephant B.

Freitas (2008) evaluated Pennisetum sp. clones under intermittent cattle grazing, in the same region as that of the present experiment, 32 days after resprouting, and also observed low $\mathrm{L} / \mathrm{C}$ ratios of 0.41 and 0.36 for the tall clones IRI-381 and Elephant B, respectively. In the Cerrado region of the state of Mato Grosso, Brazil, Fava (2008) observed L/C ratios of 0.52 , in the rainy season, and of 0.66 in the dry one. Values greater than 1.0 indicate a forage with high nutritional quality for pasture; therefore, it is an important variable for selecting elephant grass clones. It should be noted that Taiwan A-146 2.37 showed a low L/C mean ratio of
0.97 for a short clone (Table 2). Therefore, the obtained results are indicative that Mott and Taiwan A-146 2.114 should be recommended as pasture for feeding small ruminants.

Internode length differed significantly between the short clones Mott and Taiwan A-146 2.114, as well as between the tall ones IRI-381 and Elephant B, in all pasture cycles evaluated (Table 2). Contrastingly, there were no significant differences between Taiwan A-146 2.37 and Elephant B, in the sixth, seventh, eighth, and sixteenth cycles; the first genotype - despite being considered a short one - showed a greater trend toward internode elongation than Mott and Taiwan A-146 2.114. In general, these last clones had shorter internodes, with means of 3.9 and $4.7 \mathrm{~cm}$, respectively, over the ten cycles. The observed data again reinforce the potentially better viability of using the Mott and Taiwan A-146 2.114 genotypes as pasture for small ruminants, since these grasses are better adapted to grazing due to their shorter internode elongations and, consequently, lower canopy height.

Almeida et al. (2000a) studied Mott subjected to grazing, under four levels of forage availability (3.8, $7.5,10.2$, and $14.0 \mathrm{~kg}$ dry matter per $100 \mathrm{~kg}$ live weight), and found internode length values varying from 0.2 to $1.1 \mathrm{~cm}$ for the smallest and largest forage availabilities, respectively. The authors observed a linear reduction in internode length with decreasing forage availability.

The plant height between the clones differed in all grazing cycles. Mott showed the lowest height, varying from $83 \mathrm{~cm}$ in the seventh cycle to $63 \mathrm{~cm}$ in the ninth, fifteenth, and sixteenth; the clone's overall mean was $68.3 \mathrm{~cm}$. The tall clones, mainly IRI-381, had higher mean plant heights, with an extreme value of $143 \mathrm{~cm}$ in the fifth cycle and an overall mean of $113.8 \mathrm{~cm}$. Therefore, the mean height of the short clones was $28.6 \%$ lower than that of the tall ones.

Galdino (2010) reported difficulties in achieving the desired post-grazing residual heights below 80 $\mathrm{cm}$ when using the IRI-381 and Elephant B clones, probably due to their growth habits under intermittent grazing, which promote the accumulation of culms along the cycles. Therefore, tall elephant grass clones certainly show a limiting growth habit for use as pasture for small ruminants; this is attributed to their rapid culm elongation and maturation, often resulting in heights outside the reach of animals, leading to 
culm accumulation and management difficulties over multiple cycles.

It was observed that the sheep had a somewhat difficult time to reduce, via grazing, the heights of the tall clones to the desired residual height of $0.3 \mathrm{~m}$. Additionally, there was grazing unevenness, which promotes the residual accumulation of the culm fraction in pastures, hindering later regrowth and, especially, reducing forage availability to the animals. Due to the accumulation of culms over the cycles, mechanical mowing was necessary in the fifth and thirteenth ones, in order to lower the canopy of the two tall clones to the desired residual height.

The lower plant heights, combined with higher L/C ratios, of the short clones Mott and Taiwan A-146 2.114 show their greater potential for adaptation and management under grazing by small ruminants. These characteristics, therefore, have great practical implications for increasing grazing efficiency and animal performance, while reducing production costs by not requiring potential interventions to lower the pastures, as highlighted by Pereira et al. (2014).
Mean canopy height and internode length had a quadratic relationship (Figure 2). Rêgo et al. (2002) reported similar behavior when evaluating the internode length of the basal tillers of Tanzania grass (Panicum maximum Jacq. cultivar Tanzania-1) subjected to different pasture heights $(24,26,43,45$, $52,62,73$, and $78 \mathrm{~cm})$ and sampling periods $(28,56$, and 84 days). As is the case for other species of forage plants, the variations in the canopy height of elephant grass are due to culm elongation, which is affected by variations in internode length.

The proportion of leaf blade tissues differed among the evaluated clones (Table 3). The tall clone Elephant B showed the largest proportion of sclerenchyma, compared with the others. According to Wilson et al. (1993), the sclerenchyma has a thick and lignified cell wall, resulting in low digestibility; therefore, this tissue potentially represents a physical limitation to digestion. Brito et al. (1999) evaluated three cultivars of elephant grass with different regrowth ages $(6,8$, and 16 weeks), in order to determine tissue proportions in leaves and culms, as well as the tissue degradation

Table 2. Leaf blade/culm ratio, internode length, and pre-grazing height of the evaluated elephant grass (Pennisetum purpureum) genotypes, over ten grazing cycles ${ }^{(1)}$.

\begin{tabular}{|c|c|c|c|c|c|c|c|c|c|c|c|}
\hline \multirow[t]{2}{*}{ Genotype } & \multicolumn{10}{|c|}{ Grazing cycle } & \multirow[t]{2}{*}{ Mean } \\
\hline & $1^{\text {st }}$ & $2^{\text {nd }}$ & $5^{\text {th }}$ & $6^{\text {th }}$ & $7^{\text {th }}$ & $8^{\text {th }}$ & $9^{\text {th }}$ & $10^{\text {th }}$ & $15^{\text {th }}$ & $16^{\text {th }}$ & \\
\hline & \multicolumn{11}{|c|}{ Leaf blade/culm ratio } \\
\hline Taiwan A-146 2.37 & $1.02 \mathrm{ab}$ & $0.96 \mathrm{a}$ & $0.58 \mathrm{ab}$ & $0.72 b$ & $0.68 \mathrm{c}$ & $1.23 \mathrm{a}$ & $1.43 \mathrm{abc}$ & $1.21 \mathrm{~b}$ & $0.71 b$ & $1.18 \mathrm{ab}$ & 0.97 \\
\hline Taiwan A-146 2.114 & $1.02 \mathrm{ab}$ & $1.02 \mathrm{a}$ & $0.67 \mathrm{ab}$ & $1.54 \mathrm{a}$ & $1.21 \mathrm{ab}$ & $1.59 \mathrm{a}$ & $1.97 \mathrm{a}$ & $1.29 b$ & $1.84 \mathrm{a}$ & $1.56 \mathrm{ab}$ & 1.37 \\
\hline Mott & $1.31 \mathrm{a}$ & $1.01 \mathrm{a}$ & $0.97 \mathrm{a}$ & $1.45 \mathrm{a}$ & $1.42 \mathrm{a}$ & $1.64 \mathrm{a}$ & $1.84 \mathrm{ab}$ & $1.90 \mathrm{a}$ & $1.29 \mathrm{ab}$ & $1.86 \mathrm{a}$ & 1.47 \\
\hline IRI-381 & $0.90 \mathrm{~b}$ & $0.33 b$ & $0.54 \mathrm{ab}$ & $0.94 b$ & $0.96 \mathrm{bc}$ & $1.27 \mathrm{a}$ & $1.34 \mathrm{bc}$ & $1.30 \mathrm{~b}$ & $0.80 \mathrm{~b}$ & $0.85 b$ & 0.92 \\
\hline Elephant B & $0.79 b$ & $0.60 \mathrm{ab}$ & $0.44 \mathrm{~b}$ & $0.91 b$ & $1.11 \mathrm{ab}$ & $1.08 \mathrm{a}$ & $1.23 \mathrm{c}$ & $1.24 \mathrm{~b}$ & $0.58 \mathrm{~b}$ & $1.12 \mathrm{ab}$ & 0.91 \\
\hline \multirow[t]{2}{*}{$\mathrm{CV}(\%)$} & 16.5 & 28.8 & 30.1 & 12.8 & 16.8 & 25.9 & 15.4 & 17.9 & 36.8 & 28.4 & 15.1 \\
\hline & \multicolumn{11}{|c|}{ Internode length (cm) } \\
\hline Taiwan A-146 2.37 & $6.0 \mathrm{~b}$ & $5.5 b$ & $6.5 b$ & $8.0 \mathrm{bc}$ & $7.7 \mathrm{bc}$ & $7.0 \mathrm{~b}$ & $5.0 \mathrm{~b}$ & $4.2 b$ & $7.2 \mathrm{~b}$ & $8.0 \mathrm{~b}$ & 6.5 \\
\hline Taiwan A-146 2.114 & $4.5 b$ & $5.5 b$ & $5.2 b$ & $5.5 \mathrm{~cd}$ & $6.5 c$ & $5.2 \mathrm{c}$ & $3.7 \mathrm{~b}$ & $4.0 \mathrm{~b}$ & $4.0 \mathrm{c}$ & $3.2 \mathrm{c}$ & 4.7 \\
\hline Mott & $4.0 \mathrm{~b}$ & $3.2 b$ & $4.0 \mathrm{~b}$ & $4.2 \mathrm{~d}$ & $4.7 \mathrm{c}$ & $5.0 \mathrm{c}$ & $3.2 b$ & $3.7 \mathrm{~b}$ & $3.5 \mathrm{c}$ & $3.7 \mathrm{c}$ & 3.9 \\
\hline IRI-381 & $9.3 \mathrm{a}$ & $9.5 \mathrm{a}$ & $13.5 \mathrm{a}$ & $11.0 \mathrm{a}$ & $12.2 \mathrm{a}$ & $10.2 \mathrm{a}$ & $9.5 \mathrm{a}$ & $8.5 \mathrm{a}$ & $11.5 \mathrm{a}$ & $10.5 \mathrm{a}$ & 10.6 \\
\hline Elephant B & $8.8 \mathrm{a}$ & $9.5 \mathrm{a}$ & $12.5 \mathrm{a}$ & $10.2 \mathrm{ab}$ & $10.5 \mathrm{ab}$ & $8.2 \mathrm{~b}$ & $8.0 \mathrm{a}$ & $8.2 \mathrm{a}$ & $10.7 \mathrm{a}$ & $9.7 \mathrm{ab}$ & 9.6 \\
\hline \multirow[t]{2}{*}{ CV $(\%)$} & 15.3 & 20.9 & 14.5 & 16.3 & 18.9 & 9.6 & 16.0 & 10.4 & 12.7 & 11.7 & 12.1 \\
\hline & \multicolumn{11}{|c|}{ Pre-grazing height $(\mathrm{cm})$} \\
\hline Taiwan A-146 237 & $86 b c$ & $67 \mathrm{c}$ & $62 b$ & $97 \mathrm{ab}$ & $91 b$ & $69 \mathrm{~b}$ & $63 b$ & $54 b$ & $95 \mathrm{ab}$ & $85 \mathrm{ab}$ & 76.9 \\
\hline Taiwan A-146 2114 & $92 b$ & $93 b$ & $76 b$ & $77 b$ & $89 b$ & $74 b$ & $65 b$ & $63 a b$ & $70 \mathrm{ab}$ & $65 b$ & 76.4 \\
\hline Mott & $65 c$ & $65 c$ & $69 b$ & $80 \mathrm{~b}$ & $83 b$ & $68 \mathrm{~b}$ & $63 b$ & $64 \mathrm{ab}$ & $63 b$ & $63 b$ & 68.3 \\
\hline IRI-381 & $123 \mathrm{a}$ & $125 \mathrm{a}$ & $143 a$ & $120 \mathrm{a}$ & $139 \mathrm{a}$ & $110 \mathrm{a}$ & $100 \mathrm{a}$ & $78 \mathrm{a}$ & $102 \mathrm{a}$ & $98 \mathrm{a}$ & 113.8 \\
\hline Elephant B & $108 \mathrm{ab}$ & $113 a$ & $137 \mathrm{a}$ & $98 \mathrm{ab}$ & $102 \mathrm{ab}$ & $84 \mathrm{~b}$ & $70 \mathrm{~b}$ & $63 \mathrm{ab}$ & $81 \mathrm{ab}$ & $75 \mathrm{ab}$ & 93.1 \\
\hline CV (\%) & 12.0 & 8.2 & 10.4 & 11.2 & 16.1 & 13.1 & 13.2 & 11.8 & 18.5 & 15.9 & 13.1 \\
\hline
\end{tabular}

${ }^{(1)}$ Means followed by equal letters, in the columns, do not differ by Tukey's test, at $5 \%$ probability. CV, coefficient of variation. 
sequence after a liquid in vitro incubation with cattle rumen microflora. The authors concluded that the degradation of the tissues decreases with plant age, except for leaf sheath. Bauer et al. (2008) studied the influence of anatomical traits and lignification sites on the nutritional value of leaf blades of four grasses: molasses grass (Melinis minutiflora P.Beauv.), signal grass [Urochloa decumbens (Stapf) R.D.Webster (Syn. Brachiaria decumbens Stapf)], Brazilian satintail (Imperata brasiliensis Trin.), and jaragua grass [Hyparrhenia rufa (Nees) Stapf]. These authors reported that low digestibility coefficients are related to large proportions of sclerenchyma.

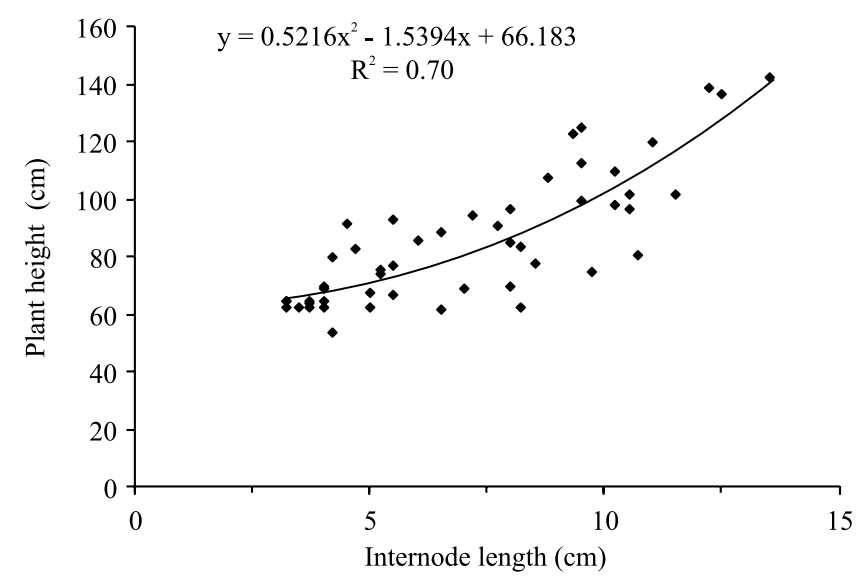

Figure 2. Relationship between internode length and mean plant height of the evaluated elephant grass (Pennisetum purpureum) genotypes, over ten grazing cycles.
The proportions of abaxial epidermis did not differ between genotypes, contrasting with adaxial epidermis, which was found in a larger proportion in IRI-381, compared with Elephant B and Mott. The leaf epidermis is considered to be slowly and only partially digestible, constituting the first barrier to be broken by microorganisms during digestion (Paciullo et al., 2002).

The Mott clone showed the largest area occupied by bulliform cells, differing from all other genotypes. According to Lempp (2007), these cells play an important role in leaf protection against water loss by transpiration, which is a potentially important trait for the adaptation of clones to environments with marked water deficits. The author also stated that, due to the larger volume of bulliform cells, their internal periclinal walls are thinner, suggesting a greater degradation compared with epidermal cells. Wilson et al. (1997) confirmed the high degradability of bulliform cells, which are similar to the parenchymal tissue, with thin cell walls covered by a thin cuticle, favoring rapid digestion. Araújo et al. (2010) evaluated, in situ, ruminal degradation and neutral detergent fiber in the dry matter of dwarf elephant grass clones, including Mott, at different cutting intervals $(14,28,42,56,70$, and 84 days); the authors concluded that potential and effective degradability do not differ between clones and that both decrease substantially with increasing plant maturity.

IRI-381 showed a larger proportion of mesophyll than Mott and did not differ from the other clones. Larger mesophyll proportions are found in the leaf

Table 3. Tissue proportions (\%) and number of vascular bundles in the leaf blades of the evaluated elephant grass (Pennisetum purpureum) genotypes ${ }^{(1)}$.

\begin{tabular}{|c|c|c|c|c|c|c|}
\hline \multirow[t]{2}{*}{ Leaf blade tissue } & \multicolumn{5}{|c|}{ Genotype } & \multirow{2}{*}{$\begin{array}{c}\text { Coefficient of } \\
\text { variation } \\
(\%)\end{array}$} \\
\hline & Mott & $\begin{array}{c}\text { Taiwan A-146 } \\
2.37\end{array}$ & $\begin{array}{c}\text { Taiwan A-146 } \\
2.114\end{array}$ & IRI-381 & Elephant B & \\
\hline Sclerenchyma & $0.65 b$ & $0.77 b$ & $0.54 \mathrm{~b}$ & $0.79 b$ & $1.35 \mathrm{a}$ & 27.39 \\
\hline Abaxial epidermis & $16.33 \mathrm{a}$ & $16.77 \mathrm{a}$ & $16.40 \mathrm{a}$ & $14.68 \mathrm{a}$ & $14.41 \mathrm{a}$ & 8.05 \\
\hline Adaxial epidermis & $10.81 b$ & $11.98 \mathrm{ab}$ & $11.25 \mathrm{ab}$ & $13.56 \mathrm{a}$ & $10.46 b$ & 9.94 \\
\hline Bulliform cells & $9.48 \mathrm{a}$ & $5.91 b c$ & $6.86 \mathrm{~b}$ & $5.53 \mathrm{bc}$ & $5.05 \mathrm{c}$ & 12.00 \\
\hline Total vascular bundle & $19.14 \mathrm{ab}$ & $19.40 \mathrm{ab}$ & $20.01 \mathrm{ab}$ & $17.44 b$ & $20.97 \mathrm{a}$ & 7.71 \\
\hline Phloem & $1.73 \mathrm{a}$ & $1.76 \mathrm{a}$ & $1.70 \mathrm{a}$ & $1.42 \mathrm{a}$ & $1.74 \mathrm{a}$ & 11.11 \\
\hline Vascular sheath & $12.76 \mathrm{a}$ & $11.83 \mathrm{ab}$ & $12.43 \mathrm{ab}$ & $11.01 \mathrm{~b}$ & $13.03 \mathrm{a}$ & 5.41 \\
\hline Xylem with associated fibers & $4.92 \mathrm{a}$ & $5.79 \mathrm{a}$ & $5.87 \mathrm{a}$ & $5.00 \mathrm{a}$ & $6.20 \mathrm{a}$ & 17.90 \\
\hline Mesophyll & $43.57 b$ & $45.16 \mathrm{ab}$ & $44.92 \mathrm{ab}$ & $48.04 \mathrm{a}$ & $47.73 \mathrm{ab}$ & 4.10 \\
\hline Number of vascular bundles & $3.72 \mathrm{ab}$ & $4.05 \mathrm{a}$ & $3.45 \mathrm{bc}$ & $3.83 \mathrm{ab}$ & $3.12 \mathrm{c}$ & 4.67 \\
\hline
\end{tabular}

(1)Means followed by equal letters, in the rows, do not differ by Tukey's test, at $5 \%$ probability. 
blades of plants that have greater potential for ruminal degradation, since that tissue is made up of cells with a thin, non-lignified wall (Bauer et al., 2008).

Elephant B showed a larger proportion of total vascular bundle, compared with IRI-381, but did not differ from the other clones. By contrast, this same clone had the lowest number of bundles in the leaf blade tissues, although it did not significantly differ from Taiwan A-146 2.114 (Table 2). It should be pointed out that a large number of vascular bundles can increase leaf blade stiffness due to the larger proportion of sclerenchyma rings, resulting in a reduced digestion of tissues.

Despite the observed differences between tall and short clones, the proportions of leaf blade tissues did not differ greatly. This may be attributed to the time of collection of the material for anatomical characterization, at 32 days after resprouting. It is also possible that these materials might actually not differ significantly from each other, independently of the manner in which they are handled and the age at which they are evaluated. Therefore, the obtained results do not clarify whether the leaf blades of the short clones are superior to those of the tall ones. Indeed, it is probable that there are no marked differences in the constituents of the leaf blade tissues of the differentsized elephant grass clones; these differences are more likely to be due to the composition of the culms with advanced maturity.

\section{Conclusions}

1. The differences in morphological characteristics indicate that the short elephant grass (Pennisetum purpureum) clones Mott and Taiwan A-164 2.114 are better adapted to sheep grazing and may be recommended for the improvement of pastures.

2. The proportions of the leaf blade tissues do not reveal sufficient anatomical differences between short and tall elephant grass clones to estimate their potential forage quality 32 days after resprouting.

\section{Acknowledgments}

To Conselho Nacional de Desenvolvimento Científico e Tecnológico (CNPq) and to Banco do Nordeste do Brasil S.A. (BNB), for financial support; and to Fundação de Amparo à Ciência e Tecnologia do
Estado de Pernambuco (Facepe), for financial support and scholarship (process number IBPG-0232-5.04/09).

\section{References}

ALMEIDA, E.X. de; MARASCHIN, G.E.; HARTHMANN, O.E.L.; RIBEIRO FILHO, H.M.N.; SETELICH, E.A. Oferta de forragem de capim-elefante anão 'Mott' e a dinâmica da pastagem. Revista Brasileira de Zootecnia, v.29, p.1281-1287, 2000a. DOI: 10.1590/S1516-35982000000500004.

ALMEIDA, E.X. de; MARASCHIN, G.E.; HARTHMANN, O.E.L.; RIBEIRO FILHO, H.M.N.; SETELICH, E.A. Oferta de forragem de capim-elefante anão 'Mott' e o rendimento animal. Revista Brasileira de Zootecnia, v.29, p.1288-1295, 2000b. DOI: 10.1590/S1516-35982000000500005.

ARAÚJO, S.A. do C.; VÁSQUEZ, H.M.; SILVA, J.F.C. da; DEMINICIS, B.B.; CAMPOS, P.R. de S.S.; LISTA, F.N. Degradação ruminal e estimativa de consumo de genótipos de capim-elefante anão. Revista Brasileira de Zootecnia, v.39, p.1824, 2010. DOI: /10.1590/S1516-35982010000100003.

ARAÚJO, S.A.C.; VASQUEZ, H.M.; SILVA, J.F.C.; LIMA, E.S.; LISTA, F.N.; DEMINICIS, B.B.; CAMPOS, P.R.S.S. Produção de matéria seca e composição bromatológica de genótipos de capimelefante anão. Archivos de Zootecnia, v.60, p.83-91, 2011. DOI: 10.4321/S0004-05922011000100010.

BAUER, M. de O.; GOMIDE, J.A.; SILVA, E.A.M. da; REGAZZI, A.J.; CHICHORRO, J.F. Características anatômicas e valor nutritivo de quatro gramíneas predominantes em pastagem natural de Viçosa, MG. Revista Brasileira de Zootecnia, v.37, p.9-17, 2008. DOI: 10.1590/S1516-35982008000100002.

BRITO, C.J.F.A de; RODELLA, R.A.; DESCHAMPS, F.C.; ALQUINI, Y. Anatomia quantitativa e degradação in vitro de tecidos em cultivares de capim-elefante (Pennisetum purpureum Schumach.). Revista Brasileira de Zootecnia, v.28, p.223-229, 1999. DOI: 10.1590/S1516-35981999000200001.

BRITO, C.J.F.A. de; DESCHAMPS, F.C. Caracterização anatômica em diferentes frações de cultivares de capim-elefante (Pennisetum purpureum Schumach.). Revista Brasileira de Zootecnia, v.30, p.1409-1417, 2001. DOI: 10.1590/S151635982001000600004 .

CUNHA, M.V. da; SANTOS; M.V.F. dos; LIRA, M. de A.; MELLO, A.C.L. de; FREITAS, E.V. de; APOLINÁRIO, V.X. de O. Genótipos de capim-elefante sob pastejo no período de seca na Zona da Mata de Pernambuco: fatores relacionados à eficiência de pastejo. Revista Brasileira de Zootecnia, v.36, p.291-300, 2007. DOI: $10.1590 / \mathrm{S} 1516-35982007000200004$

DESCHAMPS, F.C.; BRITO, C.J.F.A. de. Qualidade da forragem e participação relativa na produção de matéria seca de diferentes frações de cultivares de capim-elefante (Pennisetum purpureum Schumach.). Revista Brasileira de Zootecnia, v.30, p.1418-1423, 2001. DOI: $10.1590 /$ S1516-35982001000600005.

FAVA, A.R. Avaliação de clones de capim-elefante (Pennisetum purpureum Schum) para utilização de capineira 
no cerrado matogrossense. 2008. 76p. Dissertação (Mestrado) Universidade Federal do Mato Grosso, Cuiabá.

FERREIRA, G.D.G.; EMILE, J.-C.; BARRIÈRE, Y.; JOBIM, C.C. Caracterização morfoanatômica do colmo de híbridos de milho para avaliar a qualidade de silagem. Acta Scientiarum. Animal Science, v.29, p.249-254, 2007.

FLORES, J.A.; MOORE, J.E.; SOLLENBERGER, L.E. Determinants of forage quality in Pensacola bahiagrass and Mott elephantgrass. Journal of Animal Science, v.71, p.1606-1614, 1993. DOI: $10.2527 / 1993.7161606 x$.

FREITAS, E.V. de. Caracterização de pastos, consumo e desempenho de vacas em pastagens de Pennisetum sp. 2008. 88p. Tese (Doutorado) - Universidade Federal Rural de Pernambuco, Universidade Federal da Paraíba, Universidade Federal do Ceará, Recife.

GALDINO, A.C. Respostas morfológicas e produtivas de gramíneas forrageiras tropicais à intensidade de pastejo. 2010. 68p. Dissertação (Mestrado) - Universidade Federal Rural de Pernambuco, Recife.

ITEP. Instituto de Tecnologia de Pernambuco. Available at: $<$ http://www.itep.br>. Accessed on: June 2012.

LEMPP, B. Avanços metodológicos da microscopia na avaliação de alimentos. Revista Brasileira de Zootecnia, v.36, p.315-329, 2007. Suplemento especial. DOI: 10.1590/S151635982007001000029.

PACIULLO, D.S.C.; GOMIDE, J.A.; SILVA, E.A.M. da; QUEIROZ, D.S.; GOMIDE, C.A.M. Degradação in vitro de tecidos da lâmina foliar e do colmo de gramíneas forrageiras tropicais, em função do estádio de desenvolvimento. Revista Brasileira de Zootecnia, v.31, p.900-907, 2002. Suplemento. DOI: $10.1590 / \mathrm{S} 1516-35982002000400013$.

PEREIRA, T.P.; MODESTO, E.C.; CAMPANA, L.L.; GOMIDE, C.A. de M.; PACIULLO, D.S.C.; NEPOMUCENO, D. de D.; CARVALHO, C.A.B. de; MACEDO, R.O.; ALMEIDA, J.C. de C. Comportamento diurno de novilhas em pastagens de clones de capim-elefante anão. Revista Acadêmica de Ciências Agrárias e Ambientais, v.11, p.383-394, 2014. DOI: 10.7213/ academico.011.004.AO05.

RÊGO, F.C. de A.; CECATO, U.; CANTO, M.W. do; MARTINS, E.N.; SANTOS, G.T. dos; CANO, C.P.; PETERNELLI, M. Características morfológicas e índice de área foliar do capimtanzânia (Panicum maximum Jacq. cv. Tanzânia-1) manejado em diferentes alturas, sob pastejo. Revista Brasileira de Zootecnia, v.31, p.1931-1937, 2002. DOI: 10.1590/S1516-35982002000800008.

RESENDE, K.T. de; MEDEIROS, A.N. de; PEREIRA FILHO, J.M.; YÁÑEZ, E.A.; TEIXEIRA, I.A.M. de A.; FREGADOLLI, F.L. Produção de leite de cabras em regime de pasto. In: SEMINÁRIO NORDESTINO DE PECUÁRIA, 6.; SEMANA
DA CAPRINO-OVINOCULTURA BRASILEIRA, 3.; FEIRA DE PRODUTOS E DE SERVIÇOS AGROPECUÁRIOS, 6., 2002, Fortaleza. Anais. Fortaleza: SEBRAE, 2002. p.203-215.

SANTOS, H.G. dos; JACOMINE, P.K.T.; ANJOS, L.H.C. dos; OLIVEIRA, V.A. de; OLIVEIRA, J.B. de; COELHO, M.R.; LUMBRERAS, J.F.; CUNHA, T.J.F. (Ed.). Sistema brasileiro de classificação de solos. 2.ed. Rio de Janeiro: Embrapa Solos, 2006. 306p.

SILVA, D.S.; GOMIDE, J.A.; QUEIROZ, A.C. Pressão de pastejo em pastagem de capim-elefante anão (Pennisetum purpureum Schum). 2. Efeito sobre o valor nutritivo, consumo de pasto e produção de leite. Revista Brasileira de Zootecnia, v.23, p.453464, 1994.

SILVA, S.H.B. da; SANTOS, M.V.F. dos; LIRA, M. de A.; DUBEUX JUNIOR, J.C.B.; FREITAS, E.V. de; FERREIRA, R.L.C. Uso de descritores morfológicos e herdabilidade de caracteres em clones de capim-elefante de porte baixo. Revista Brasileira de Zootecnia, v.38, p.1451-1459, 2009. DOI: 10.1590/ S1516-35982009000800008.

VEIGA, J.B. Utilização do capim-elefante sob pastejo. In: CARVALHO, M.M.; ALVIN, M.J.; XAVIER, D.F.; CARVALHO, L. de A. (Ed.). Capim-elefante: produção e utilização. Coronel Pacheco: EMBRAPA-CNPGL, 1994. p.165-193.

VIANA, B.L.; MELLO, A.C.L. de; LIRA, M. de A.; DUBEUX JÚNIOR, J.C.B.; SANTOS, M.V.F. dos; CUNHA, M.V. da; FERREIRA, G.D.G. Repetibilidade e respostas de características morfofisiológicas e produtivas de capim-elefante de porte baixo sob pastejo. Pesquisa Agropecuária Brasileira, v.44, p.17311738, 2009. DOI: 10.1590/S0100-204X2009001200024.

VIANA, B.L.; MELLO, A.C.L. de; LIRA, M. de A.; GUIM, A.; DUBEUX JR., J.C.B.; SANTOS, M.V.F. dos; CUNHA, M.V. da. Adaptability and stability analysis for selection of elephantgrass clones under grazing. Crop Science, v.55, p.950-957, 2015. DOI: 10.2135/cropsci2014.05.0406.

VIEIRA, F.T.P. de A.; SILVA, J.A.A. da; FERREIRA, R.L.C.; CRUZ, M.A.O.M. da; FERRAZ, I. Uma abordagem multivariada em experimento silvipastoril com Leucaena leucocephala (Lam.) de Wit no Agreste de Pernambuco. Ciência Florestal, v.17, p.333342, 2007. DOI: 10.5902/198050981965.

WILSON, J.R.; MERTENS, D.R.; HATFIELD, R.D. Isolates of cell types from sorghum stems: digestion, cell wall and anatomical characteristics. Journal of the Science of Food and Agriculture, v.63, p.407-417, 1993. DOI: 10.1002/jsfa.2740630406.

WILSON, J.R.; HATFIELD, R.D. Structural and chemical changes of cell wall types during stem development: consequences for fibre degradation by rumen microflora. Australian Journal of Agricultural Research, v.48, p.165-180, 1997. DOI: 10.1071/ A96051.

Received on February 22, 2017 and accepted on February 23, 2018

Pesq. agropec. bras., Brasília, v.53, n.11, p.1268-1275, Nov. 2018 DOI: $10.1590 / \mathrm{S} 0100-204 \mathrm{X} 2018001100009$ 